\title{
Kuat Tekan Vertikal Dinding Panel Beton Expanded Polystyrene dengan Perkuatan Papan Kalsium Silikat dan Penyambung Geser Baut
}

\author{
(The Vertical Compressive Strength of Expanded Polystyrene Concrete Wall Panels with Reinforcement \\ of Calcium Silicate Board and Bolt Shear Connector)
}

BELla LUTFIANI Al ZAKINA, ASHAR SAPUTRA, Ali AWALUdiN

\begin{abstract}
ABSTRAK
Perlunya percepatan penyediaan rumah tinggal mengharuskan pemerintah mencoba sistem konstruksi inovatif menggunakan sistem beton sandwich polystyrene yang digunakan sebagai konstruksi dinding. Konstruksi ini memiliki kelebihan seperti memiliki bobot yang relatif lebih ringan, harga yang relatif lebih ekonomis, dan kemudahan serta kecepatan konstruksi. Konstruksi ini diharapkan dapat mengurangi risiko kerusakan akibat gempa bumi karena memiliki bobot yang relatif ringan yang merupakan salah satu syarat untuk rumah tahan gempa. Untuk meningkatkan daya dukung dinding panel beton polystyrene agar menjadi dinding struktural, alternatifnya adalah menggunakan bahan pelapis perkuatan. Dalam penelitian ini menggunakan spesimen pracetak yang diperoleh dari pracetak pabriksi dengan panjang $1800 \mathrm{~mm}$, lebar $610 \mathrm{~mm}$, dan tebal $75 \mathrm{~mm}$. Penguatan menggunakan papan Kalsium Silikat. Jenis kalsium silikat yang digunakan adalah papan Kalsi. Benda uji disabung menggunakan lem sika dan kemudian dilubangi, jika telah dilakukan pasang bautsebagai konektor geser. Variasi dalam penelitian ini adalah panel beton polystyrene polos, panel beton polystyrene yang diperkuat dengan kalsi, dan panel beton polystyrene yang diperkuat dengan kalsi dan konektor geser baut. Pengujian berdasarkan SNI 03-3122- 1992 (Panel Beton Ringan Berserat). Hasil penelitian menunjukkan bahwa nilai rata-rata berat panel adalah $612,57 \mathrm{~kg} / \mathrm{m} 3$, modulus elastisitas 942,37 MPa, kekuatan tekan 2,52 MPa dan kapasitas penyerapan air $12,11 \%$. Kekuatan tekan tertinggi diperoleh oleh panel dengan perkuatan kalsiboard sebesar 1,18 MPa. Ini menunjukkan penambahan lapisan perkuatan akan mempengaruhi peningkatan kekuatan.
\end{abstract}

Kata kunci: expanded polystyrene sandwiches, perkuatan, kuat tekan

\section{ABSTRACT}

The need to acceleration the provision of residential homes requires the government tried innovative construction system using concrete sandwiches expanded polystyrene used as wall construction. This construction has advantages such as having a relatively lighter weight, relatively more economical prices, and the ease and speed of construction. This construction is expected to reduce the risk of damage due to earthquakes because it has a relatively light weight which is one of the requirements for earthquake resistant houses. To increase the bearing capacity of expanded polystyrene concrete panel walls to be a structural wall, the alternative is to use reinforced coating material. In this study using precast specimens obtained from the precast manufacturing with a length of $1800 \mathrm{~mm}$, width $610 \mathrm{~mm}$, and thick $75 \mathrm{~mm}$. Strengthening using the Calcium Silicate board. The type of calcium silicate used is the Kalsi board. The test object is glued using sika glue and then drilling, if it is has done to install the bolt as a sliding connector. Variations in this study are expanded polystyrene concrete panels without reinforcement, with reinforcement, and with reinforcement and bolt shear connectors. Testing based on SNI 03-31221992 (Fibrous Lightweight Concrete Panel). The results showed that the average value of the panel weight was $612,57 \mathrm{~kg} / \mathrm{m}^{3}$, the elastic modulus was 942,37 MPa, compressive strength of 2,52 MPa and water absorption capacity of $12,11 \%$. The highest compressive strength was obtained by the panel with a calibration of 1,18 $M P a$. This shows the addition of reinforcement layers will affect the increase in strength.

Keywords: expanded polystyrene sandwiches, reinforcement, compressive strength 


\section{PENDAHULUAN}

Berawal dari suatu kebutuhan akan percepatan penyediaan rumah tinggal yang diprogramkan oleh pemerintah maka dicoba sistem konstruksi inovatif menggunakan sandwiches beton expanded polystyrene yang digunakan untuk konstruksi dinding. Salah satu keunggulan yang dimiliki beton expanded polystyrene adalah berat relatif ringan dimana hal ini merupakan salah satu syarat rumah tahan gempa.

Untuk meningkatkan daya dukung terhadap beton expanded polystyrene dilakukan perkuatan. Perkuatan dilakukan dengan cara menambahkan bahan pelapis pada sisi-sisi beton ringan expanded polystyrene.

Persoalan yang biasanya muncul pada struktur sandwich adalah masalah lekatan antara lapisan inti (core) dengan lapisan kulit (skin). Karena besar kemungkinan kegagalan disebabkan oleh lekatan yang tidak baik antara kedua lapisan tersebut (debonding). Untuk mendapatkan lekatan yang baik antara kedua elemen agar mencapai keadaan komposit monolit, maka dibutuhkan konektor yang menghubungkan lapisan kulit dan beton inti pembentuk struktur sandwich beton.

Menurut Firdaus (2013) pada konstruksi komposit, pengikatan antara lapisan kulit dan inti dapat dilakukan dengan lem (chemical bond), penggarukkan (screeding) atau dengan menggunakan konektor (mechanical connector). Ikatan antara lapisan kulit dengan lapisan inti berguna untuk menjaga agar elemen struktur sandwich tetap menyatu dan meneruskan beban antara lapisan kulit dan inti. Adhesive dan pengelasan seringkali digunakan untuk pengikatan.

Struktur sandwich merupakan struktur yang terdiri dari dua lapisan tipis, kaku dan kuat dari material padat yang dipisahkan oleh satu lapisan tebal yang terbuat dari material dengan berat jenis yang rendah, yang memiliki kekakuan dan kekuatan yang lebih rendah dari lapisan pengapitnya (Callister, 2007).

Menurut Purbotunggal (2016) dinding panel adalah salah satu hasil perkembangan teknologi dalam bidang beton pracetak. Dinding panel atau lebih dikenal panel-panel dinding merupakan salah satu komponen non struktural dari suatu bangunan. Dinding panel lebih banyak digunakan pada suatu konstruksi dibandingkan dengan penggunaan batu bata karena karakteristik dinding panel yang memiliki berat relatif ringan sehingga tidak memberikan beban yang besar bagi suatu konstruksi. Dengan karakteristik dinding panel yang lebih ringan maka sangat berguna bagi daerah yang rawan terhadap gempa. Pada umumnya karakteristik dinding panel lebih tipis bila dibandingkan dengan dinding batu bata biasa memiliki bobot yang ringan sehingga tidak menimbulkan beban yang berat bagi struktur.

Beberapa penelitian yang sudah mengembangkan beton expanded polystyrene antara lain Sulistyorini (2015) telah mengembangkan beton expanded polystyrene dengan memanfaatkan limbah styrofoam dan perkuatan berupa lapisan kawat loket yang hasilnya bahwa perkuatan memberikan pengaruh yang lebih baik daripada tanpa penggunaan perkuatan. Kafrain (2014) mengembangkan beton expanded polystyrene dengan memperkuat menggunakan lapisan kertas roti pada permukaan beton dan variasi komposisi jumlah semen, hasilnya didapatkan perkuatan meningkatkan nilai kuat tekan vertikal beton expanded polystyrene.

Penggunaan panel sandwich EPS dapat mengurangi jumlah dan ukuran balok maupun kolom,bahkan menghilangkannya. Misalnya sebuah ruangan dengan bentang balok 6 meter, tidak perlu diberikan kolom praktis. Keuntungan penggunaannya adalah menghemat waktu dan biaya, dalam hal ini pembuatan struktur kolom dan balok, dan juga mengurangi beban statis struktur. Karakteristik ini yang menyebabkan bangunan dari panel sandwich EPS cenderung tahan terhadap gempa. Dinding dengan panel sandwich EPS memiliki konduktivitas termal sebesar $10 \%$ dibandingkan dengan dinding konvensional (bata merah dan plesteran) dengan ketebalan yang sama (IAIMagazine, 2009).

\section{Metode Penelitian}

Beton expanded polystyrene dilakukan dengan menggunakan metode eksperimental. Benda uji yang digunakan pada penelitian ini didapatkan dari proses pabrik secara precast. Dimensi yang digunakan sesuai dengan pabrikasi yaitu panjang $1800 \mathrm{~mm}$, lebar 610 $\mathrm{mm}$, dan tebal $75 \mathrm{~mm}$. Dari dimensi diketahui 
bahwa benda uji beton expanded polystyrene memenuhi kriteria yang di syaratkan pada SNI 03-3122-1992. Berikut Tabel 1 yaitu toleransi dimensi untuk benda uji panel beton ringan berserat menurut SNI 03-3122- 1992.

TABEL 1. Ukuran dan Toleransi Panel Beton Ringan Berserat (SNI 03-3122-1992)

\begin{tabular}{ll}
\hline \multicolumn{1}{c}{ Ukuran } & Toleransi \\
\hline Panjang 3000 mm & $\pm 0,4 \%$ \\
Lebar 900, 600, 300 mm & $\pm 0,4 \%$ \\
Tebal $80 \mathrm{~mm}$ & $\pm 0,3 \%$ \\
& $-2 \%$ \\
\hline
\end{tabular}

Benda uji akan diperkuat dengan menggunakan lembaran rata papan kalsium silikat yang ada dipasaran yaitu Kalsi Board. Perkuatan lapisan di bedakan menjadi 2 yaitu perkuatan kalsiboard dan perkuatan kalsiboard dengan penyambung geser baut.
Sketsa benda uji untuk perkuatan kalsiboard yang ditambah dengan penyambung geser baut dapat dilihat pada Gambar 1. Pengujian kuat tekan vertikal menggunakan alat Loading Frame dan Load Cell dengan kapasitas 200 $\mathrm{kN}$, setting alat dapat dilihat pada Gambar 2 . Prosedur pelaksanaan mengacu pada SNI 033122-1992 (Panel Beton Ringan Berserat) sebagai berikut.

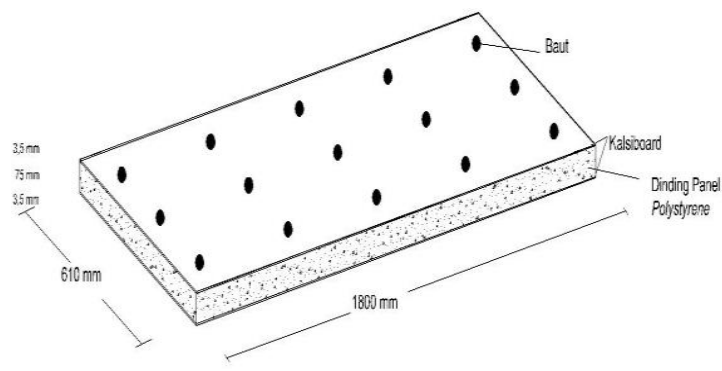

GAMBAR 1. Sketsa benda uji dengan lapisan papan kalsiboard dengan penyambung geser baut

TABEL 2. Variasi dan dimensi benda uji

\begin{tabular}{ccccc}
\hline \multirow{2}{*}{ Kode } & \multicolumn{3}{c}{ Dimensi (mm) } & Jumlah \\
& Panjang & Lebar & Tebal & \\
\hline PPT & 1800 & 610 & 75 & 3 \\
PPK & 1800 & 610 & 82 & 3 \\
PBK & 1800 & 610 & 82 & 3 \\
\hline Keterangan: & : Panel Polos Tanpa Perkuatan & \\
PPT & : Panel dengan Perkuatan Papan Kalsium Silikat & \\
PPK & : Panel dengan Perkuatan Papan Kalsium Silikat dan Penyabung Geser Baut
\end{tabular}

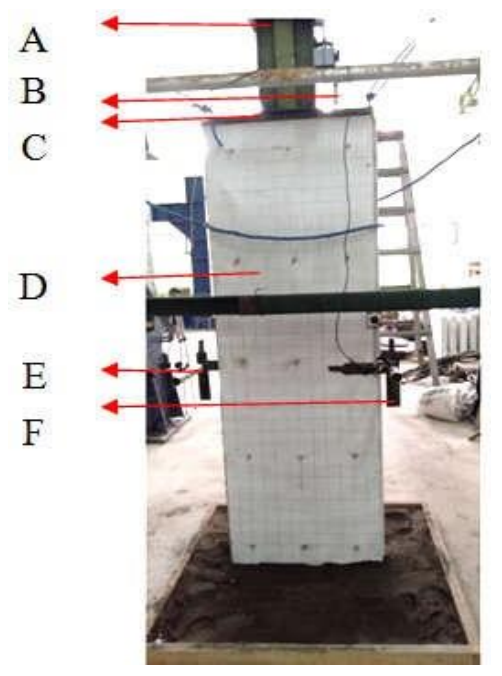

GAMBAR 2. Setting pengujian kuat tekan vertical

Keterangan :

$\mathrm{A}=$ Load Cell

$\mathrm{C}=$ Perata Beban

$\mathrm{B}=$ Lvdt Vertikal

$\mathrm{E}=$ Lvdt Horisontal

$\mathrm{D}=$ Benda Uji

$\mathrm{F}=$ Lvdt Horisontal 
Kuat tekan vertikal yang didasarkan pada rumus kuat tekan pada beton. Mengacu pada peraturan SNI 03-3122-1992, kuat tekan vertikal dinding panel dapat dihitung dengan membagi beban yang bekerja, $(\mathrm{P})$ dengan luasan permukaan yang mendapat tekanan yaitu lebar panel (b) dikali dengan tebal panel (h) seperti terlihat pada persamaan 1 .

$\mathrm{f}_{\mathrm{tk}}=\frac{\mathrm{p}}{\mathrm{b} \cdot \mathrm{h}}$

Untuk konsentrasi kekuatan papan kalsium silikat dilakukan pengujian kuat lentur. Acuan yang digunakan dalam penguji kuat lentur papan Kalsi Board menggunakan SNI 7705:2011 lembaran papan kalsium silikat.

kuat lentur $=\frac{3 \mathrm{P} \mathrm{L}}{2 \mathrm{~b} \mathrm{~h}^{2}}$

Pengujian dasar beberapa yang dilakukan antara lain daya serapan air terhadap panel beton expanded polystyrene dengan dihitung menggunakan persamaan 3 sebagai berikut.

Penyerapan Air (PA) $=\frac{w_{b}-w_{k}}{w_{k}} \times 100 \%$

Berat jenis panel beton ringan dihitung dengan rumus sebagai berikut.

$\operatorname{Bj}=\frac{W}{V}$

Dimana, $\mathrm{Bj}=$ berat jenis $\left(\mathrm{kg} / \mathrm{cm}^{3}\right), \mathrm{W}=$ berat kering $(\mathrm{kg})$, dan $\mathrm{V}=$ volume benda uji $\left(\mathrm{mm}^{3}\right)$

Modulus elastisitas panel beton ringan EPS dihitung menggunakan rumus pendekatan struktur beton ringan yaitu sebagai berikut.

$\mathrm{Ec}=0,043 \mathrm{~W}_{\mathrm{c}}^{1,5} \sqrt{\mathrm{fc}^{\prime}}$

Dimana, $\mathrm{Wc}=$ berat jenis beton ringan EPS $\left(\mathrm{kg} / \mathrm{cm}^{3}\right), \mathrm{Fc}^{\prime}=$ kuat tekan beton $(\mathrm{MPa})$, dan $\mathrm{Ec}=$ modulus elastisitas beton $(\mathrm{MPa})$.

Pengujian baut dilakukan uji tarik baut untuk mengukur ketahanan suatu material terhadap gaya statis yang diberikan secara lambat. Pengujian dilakukan pembebanan uniaxial sehingga spesimen uji mengalami peregangan dan bertambah panjang hingga akhirnya patah. Spesimen baut harus memenuhi standar dan spesifikasi dari
ASTM E8M. Bentuk spesimen harus sesuai standar untuk menghindari patah atau retak pada daerah grip atau yang lainnya. Standarisasi spesimen benda uji dimaksudkan agar retak atau patahan terjadi pada daerah gage length.

\section{HASIL DAN PEMBAHASAN}

1. Pengujian Pemeriksaan Bahan

Beton expanded polystyrene dilakukan pengujian dasar untuk mengetahui sifat dari beton ringan expanded polystyrene, dihasilkan nilai sebagai berikut pada Tabel 3 .

TABEL 3. Hasil pengujian sifat beton expanded polystyrene

\begin{tabular}{|c|c|c|}
\hline No. & Pengujian & Hasil \\
\hline 1. & Kuat tekan material & $2,52 \mathrm{MPa}$ \\
\hline 2. & Berat Jenis & $612,57 \mathrm{~kg} / \mathrm{m}^{3}$ \\
\hline 3. & Modulus Elastisitas & $942,37 \mathrm{MPa}$ \\
\hline 4. & Daya Serap Air & $12,11 \%$ \\
\hline
\end{tabular}

Pengujian pemeriksaan bahan dasar kuat lentur kalsiboard didapatkan hasil sebesar 19,19 $\mathrm{MPa}$, dan hasil pengujian kuat tarik baut diperoleh tegangan max $(\sigma \mathrm{u})$ rata-rata sebesar $532,86 \mathrm{MPa}$ dan untuk tegangan luluh $(\sigma \mathrm{y})$ rata-rata sebesar 521,57 MPa, sehingga didapat regangan dalam kondisi elastis baut sebesar $13,73 \%$.

\section{Pengujian Kuat Tekan Vetikal}

Dari pengujian kuat tekan vertikal dinding panel beton ringan EPS diperoleh nilai kuat tekan tertinggi sebesar $1,18 \mathrm{MPa}$ yang dihasilkan dari panel beton ringan EPS dengan perkuatan (PPK), sedangkan panel beton ringan EPS tanpa perkuatan (PPT) memiliki kuat tekan vertikal rerata sebesar 0,70 MPa. Untuk panel dengan perkuatan dan penyambung geser baut (PBK) memilik nilai kuat tekan vertikal rerata sebesar 1,12 MPa.

Penambahan lapis perkuatan kalsiboard pada panel beton ringan EPS memberikan pengaruh terhadap kenaikan nilai kuat tekan vertikal sebesar $\pm 68 \%$ akan tetapi pengaruh penambahan sambungan baut tidak memberikan kenaikan hasil kuat tekan.

Secara keseluruhan bahwa hasil pengujian kuat tekan vertikal pada panel beton ringan EPS dengan perkuatan kalsiboard serta penambahan penyambung geser baut ini tidak dapat memenuhi syarat SNI 03-3122-1992. Beberapa 
hal yang menyebabkan kegagalan dalam pengujian kuat tekan vertikal antara lain kegagalan terjadi pada lapisan yang tidak dapat menempel dengan sempurna sehingga benda uji tidak bekerja secara komposit. Posisi benda uji yang harus dipastikan berdiri tegak lurus vertikal saat dilakukan pengujian.

\section{a) Kerusakan Panel PPT}

Kerusakan menurut teori King (2003) pada panel beton ringan EPS tanpa perkuatan (PPT) rata-rata adalah slippage atau mengelupas permukaan pada bagian atas atau bawah plat. Pada panel beton ringan EPS tanpa perkuatan (PPT) didapatkan beban runtuh 3021,48 kg dengan lendutan terbesar 3,19 mm. Hasil dari grafik hubungan lendutan dan beban dapat dilihat pada Gambar 4, Benda uji panel polos tanpa perkuatan ini dapat dilihat pada Gambar 3.

\section{b) Kerusakan Panel PPK}

Kerusakan yang terjadi pada panel dengan perkuatan kalsiboard (PPK) berada di daerah atas atau bawah panel beton ringan EPS dimulai dengan melepasnya ikatan antara beton ringan EPS (core) dengan lapisan terluar (kulit) kalsiboard, sehingga benda uji tidak bekerja secara komposit. Retakan panel beton ringan EPS tidak dapat teramati dengan baik karena tertutup oleh lapisan luar kalsiboard. Beban yang didapatkan dari panel PPK sebesar $5443 \mathrm{~kg}$ dengan lendutan 11,14 mm. Perilaku pembebanan dapat dilihat pada Gambar 5. Kerusakan menurut teori King (2003) yang terjadi pada benda uji panel dengan perkuatan adalah bearing atau tumpuan. Kerusakan yang terjadi pada panel beton ringan dengan perkuatan kalsiboard dapat dilihat pada Gambar 6.
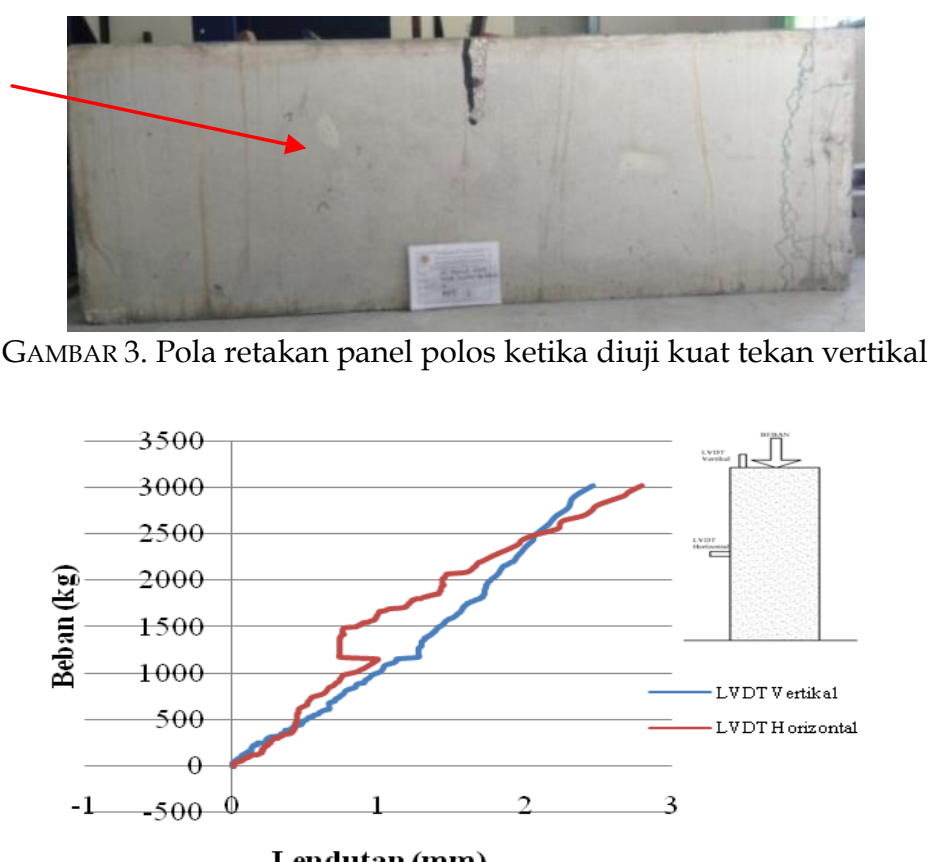

GAMBAR 4. Grafik hubungan beban dengan lendutan kuat tekan vertikal panel polos tanpa perkuatan (PPT)

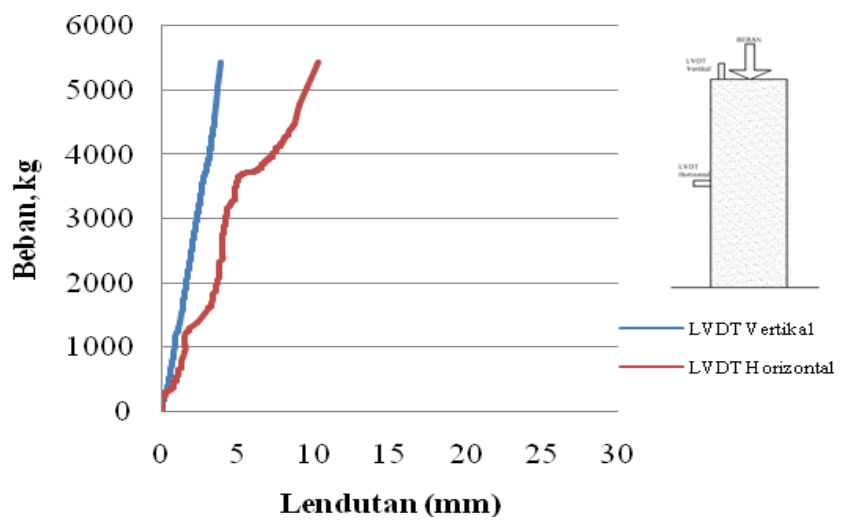

GAMBAR 5. Grafik hubungan beban dengan lendutan kuat tekan vertikal panel dengan perkuatan (PPK) 


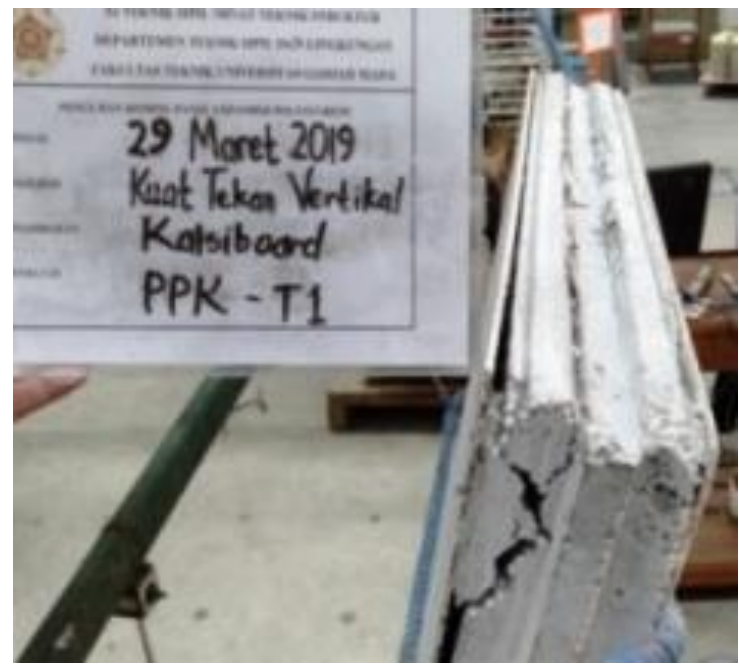

GAMBAR 6. Pola retakan panel dengan perkuatan lapisan kalsiboard tanpa penyambung baut setelah diuji kuat tekan vertical

c) Kerusakan Panel PBK

Kerusakan panel dengan perkuatan kalsiboard dan penyambung baut (PBK) ini perilaku ketika diuji rata-rata panel mengalami crack yang disertai runtuh dan lepas dari dudukan seperti Gambar 7. Kemungkinan dikarenakan retakan yang berada didalam lapisan kalsiboard tidak terlihat, dan terus diberi pembebanan sehingga panel tersebut mengalami guling dan lepas dari dudukan hingga jatuh dan patah. Benda uji (PBK) mendapat beban sebesar 7164,4 $\mathrm{kg}$ dengan lendutan 21,88 $\mathrm{mm}$. Perilaku pembebanan dapat dilihat pada Gambar 8.

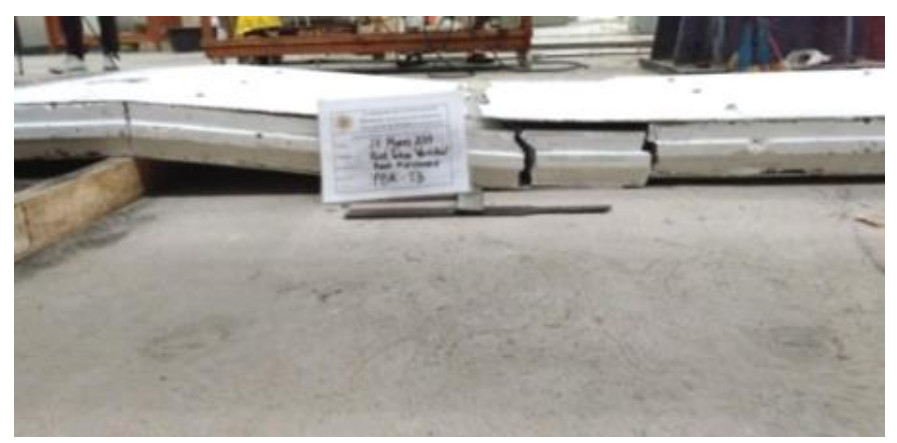

GAMBAR 7. Panel dengan perkuatan kalsiboard dengan penyambung baut setelah diuji kuat tekan vertikal (terlepas dari ikatan setting alat dan jatuh)

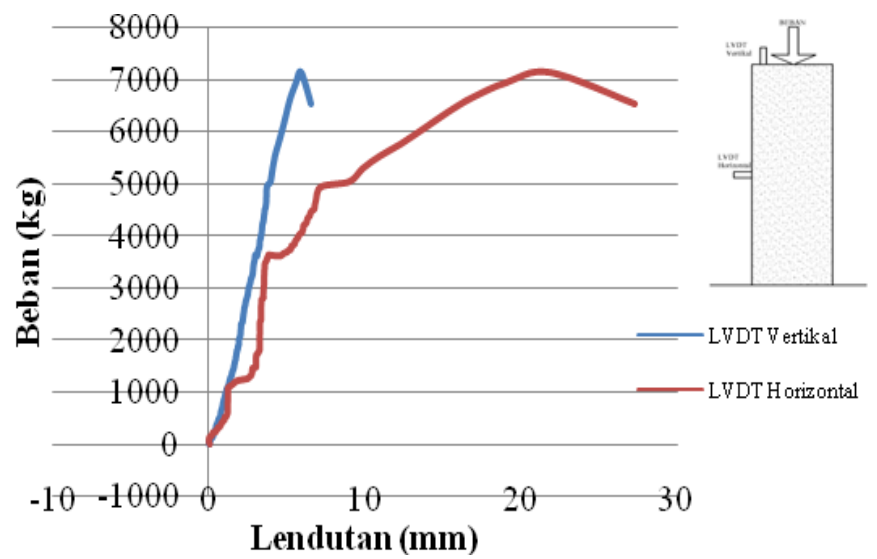

GAMBAR 8. Grafik hubungan beban dengan lendutan kuat tekan vertikal panel dengan perkuatan dan sambungan baut (PBK) 
Dari hasil pengujian ketiga variasi panel beton expanded polystyrene dapat dilihat pada Gambar 9 bahwa perbandingan hasil pengujian kuat tekan vertikal pada lendutan arah vertikal dan arah horisontal dapat dilihat pada Gambar 10 bahwa besarnya nilai lendutan tanpa perkuatan lebih kecil dibandingkan dengan menggunakan perkuatan. Sehingga penambahan perkuatan tersebut jelas dapat menaikkan kekuatan hingga panel beton expanded polystyrene tersebut dapat mempertahankan kekuatannya lebih lama dibandingkan dengan panel beton tanpa perkuatan.

Secara keseluruhan pengujian ketiga variasi panel beton expanded polystyrene dapat dilihat pada Gambar 11 dimana presentasi dapat dilihat jelas dengan perbandingan kekuatan yang di syaratkan SNI 03-3122-1992.

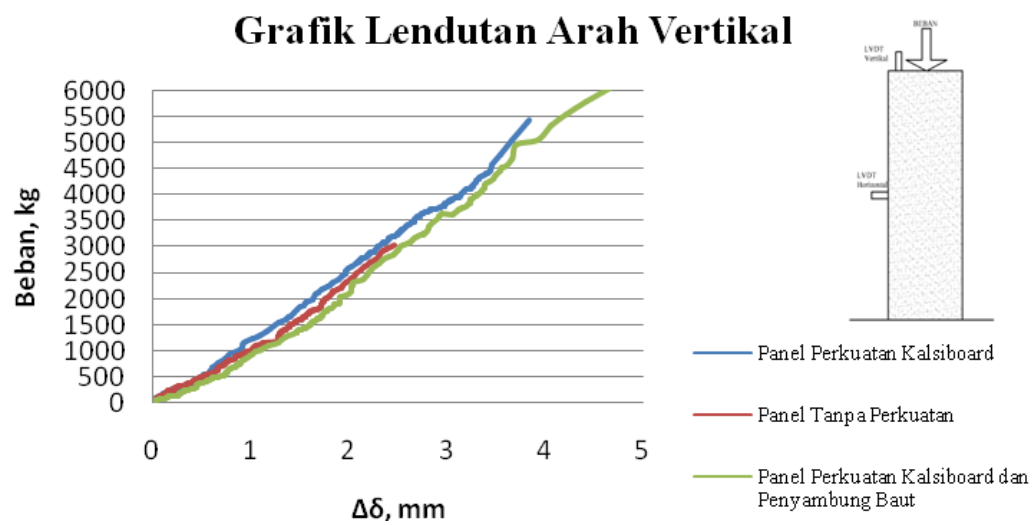

GAMBAR 9. Perbandingan hasil lendutan arah vertikal

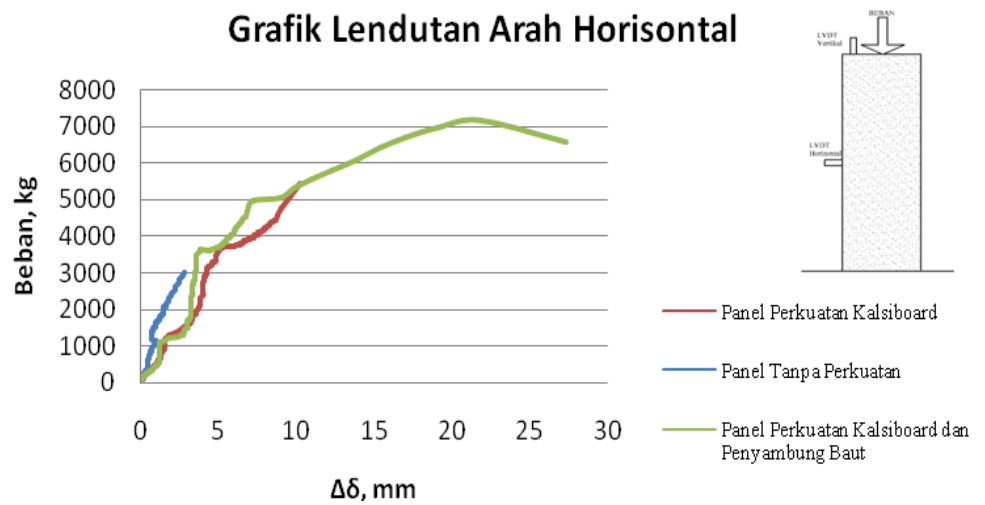

GAMBAR 10. Perbandingan hasil lendutan arah horisontal

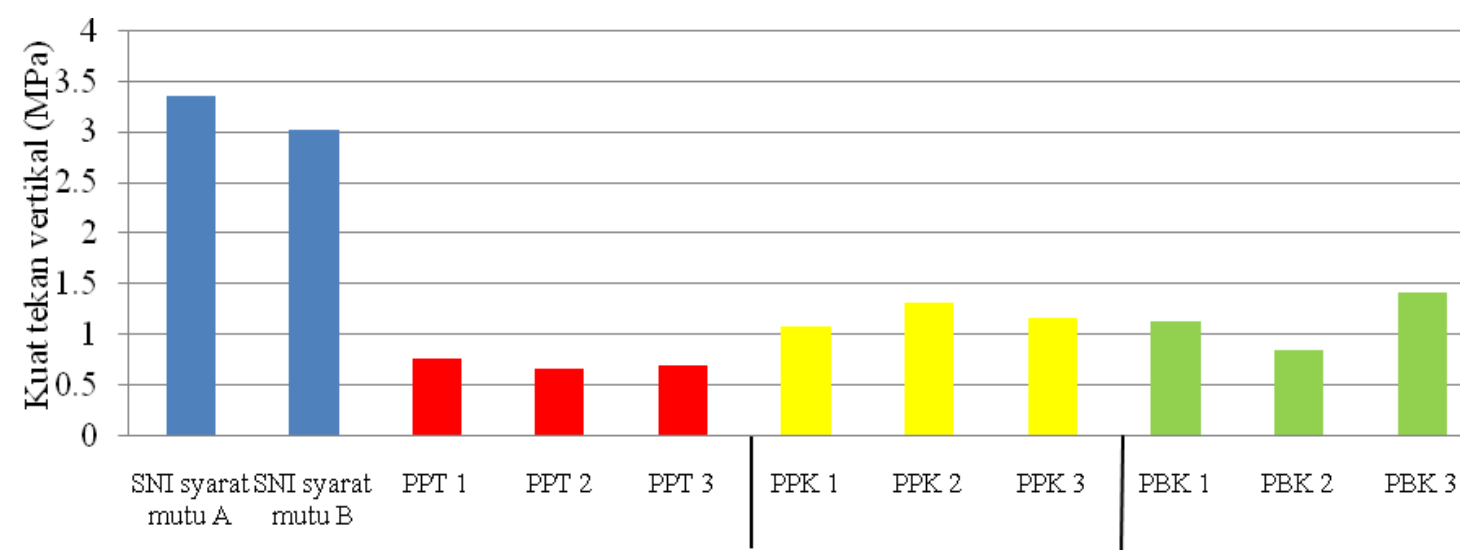

GAMBAR 11. Perbandingan hasil uji tekan vertikal panel beton polystyrene dengan syarat mutu SNI 03-3122-1992 (konversi lebar benda uji) 
KESIMPULAN

Pada penelilitian ini dilakukan perkuatan pada dinding panel expanded polystyrene yang menghasilkan nilai kuat tekan vertikal maksimum rerata sebesar 1,18 MPa pada panel beton ringan EPS dengan perkuatan kalsiboard, sedangkan nilai kuat tekan vertikal untuk panel beton ringan tanpa perkuatan sebesar 0,70 MPa, dan panel beton ringan EPS dengan perkuatan kalsiboard dan penyambung geser baut memiliki nilai kuat tekan vertikal sebesar 1,12 MPa, sehingga penambahan lapis perkuatan kalsiboard pada panel beton ringan EPS memberikan pengaruh terhadap kenaikan nilai kuat tekan vertikal sebesar $\pm 68 \%$, akan tetapi penambahan perkuatan kalsiboard dengan penyambung geser baut tidak memberikan pengaruh kenaikan dari panel perkuatan tanpa penyambung geser baut. Secara keseluruhan pengujian kuat tekan vertikal panel beton ringan EPS baik tanpa perkuatan dan menggunakan perkuatan tidak memenuhi syarat pada SNI 03-3122-1992.

\section{DAFTAR PUSTAKA}

ASTM E8/E8M. "Standard Test Methods for Tension Testing of Metallic Materials".

Badan Standarisasi Nasional Indonesia. (1992). Panel beton ringan berserat, SNI 03-3122-1992. Jakarta: Badan Standarisasi Nasional Indonesia.

Badan Standarisasi Nasional Indonesia. (2011). Lembaran Rata Kalsium Silikat, SNI 7705:2011. Jakarta: Badan Standarisasi Nasional Indonesia.

Callister, W. D. (2007), Materials Science and Engineering - An Introduction, John Wiley \& Sons, Inc.

Firdaus. (2013). Perilaku Elemen Beton Sandwich Terhadap Pengujian Geser Murni. Palembang: Universitas Bina Darma

IAIMagazine. (2009). Reinforced concreteExpanded Polystrene (EPS) Sandwich Panel: Megatrend Bahan Bangunan Hemat Energi dan Tahan Gempa." Techno Konstruksi Magazine, hal.2-6. Diakses pada 14 Mei 2019 dari http:www.b-panel.com.
Kafrain, I Gede Yohan. (2014). Pengembangan Panel Dinding Polystyrene Dengan Perkuatan Kertas Roti Di Bagian Permukaannya. Yogyakarta: Universitas Gadjah Mada.

King, (2003). Load-Bearing Straw Bale Construction. California: Ecological Building Network (EBNet), and a consulting structural engineer.

Purbotunggal, Sasongko. (2016). Kuat Geser Dinding Panel dengan Perkuatan Wiremesh. Surakarta: Universitas Muhammadiyah Surakarta.

Sulistyorini, (2015). Kuat Lentur Panel Partisi dari Limbah Styrofoam yang Dilapisi Kawat Loket. Universitas Sarjanawiyata Tamansiswa.

PENULIS:

Bella Lutfiani Al Zakina

Program Studi Teknik Sipil, Departemen Teknik Sipil dan Lingkungan, Universitas Gadjah Mada, Yogyakarta.

Email: bellazakina0104@gmail.com

\section{Ashar Saputra}

Program Studi Teknik Sipil, Departemen Teknik Sipil dan Lingkungan, Universitas Gadjah Mada, Yogyakarta.

Email: saputra@ugm.ac.id

\section{Ali Awaludin}

Program Studi Teknik Sipil, Departemen Teknik Sipil dan Lingkungan, Universitas Gadjah Mada, Yogyakarta.

Email: ali.awaludin@ugm.ac.id 